УДК: 332.12:330.15

ОЦНКА СІЛЬСЬКОГОСПОДАРСЬКОГО ПОТЕНЦАЛУ У КОНТЕКСТІ ДІАГНОСТИКИ ЕКОНОМІЧНОГО ПОТЕНЦАЛУ СІЛЬСЬКОГОСПОДАРСЬКОЇ ГАЛУЗІ ЧЕРКАСЬКОГО РЕГІОНУ

DOI 10.32782/2224-6282/152-9

JEL: O52, Q10, R10

Потапенко Т. П.

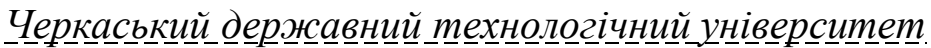
У статті запропоновано визначення для характеристики економічного потенціалу сільськогосподарської галузі регіону, зокрема як сукупність економічних ресурсів та здатність їх ефективно акумулювати і використати суб'єктами економічних відносин адміністративно-територіального утворення, які провадять господарську діяльність 3 виробництва та переробки власної сільськогосподарської продукції, що у кінцевому результаті забезпечує соціально-економічний розвиток відповідного регіону. Зазначено роль сільськогосподарського потенціалу регіону у контексті діагностики економічного потенціалу сільськогосподарської галузі на рівні регіону. Представлено структурно-логічну схему взаємозв'язку між даними категоріями. Зазначено наступні відмінності між термінами: сільськогосподарський потенціал регіону характеризує регіон, зважаючи на стан володіння наявними та перспективами залучення необхідних ресурсів для ведення сільськогосподарської діяльності, а друга категорія зорієнтована на економічну доцільність використання наявних та можливості залучення ресурсів для ведення сільськогосподарської діяльності у регіоні. Запропоновано виокремлювати в оцінці сільськогосподарського потенціалу регіону наступні складові потенціали: природній, виробничогосподарський, фінансово-інвестиційний, науково-інноваційний, трудовий та потенціал якості життя у сільській місцевості. Показники згруповано в шість інтегральних показників та порівняно з інтегральними показниками відповідних середніх значень по Україні (розраховано темпи приросту за кожен рік). Розглянуто динаміку показників, які характеризують запропоновані для оцінювання складові сільськогосподарського потенціалу, на прикладі Черкаського регіону. Виявлено, що Черкаський регіон володіє сприятливими умовами для ведення сільського господарства: значна частка капітальних інвестицій на розвиток галузі, висока концентрація навчальних та науководослідних установ, вище середнього по Україні рівень заробітної плати у галузі. Встановлено, що зважаючи на високу частку ріллі, родючість грунтів переважаючою є галузь рослинництва.

Ключові слова: потенціал; сільськогосподарський потенціал; економічний потенціал; регіон

(C) Потапенко Т. П., 2019 
UDC: $332.12: 330.15$

\section{AGRICULTURAL POTENTIAL ASSESSMENT IN THE CONTEXT OF DIAGNOSTICS OF THE AGRICULTURAL INDUSTRY ECONOMIC POTENTIAL IN CHERKASSY REGION}

DOI 10.32782/2224-6282/152-9

JEL: O52, Q10, R10

Potapenko T.

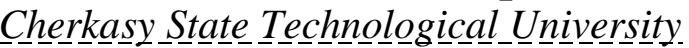

The definitions for characterizing the economic potential of region agricultural sector have been proposed, in particular as a set of economic resources and the ability to effectively accumulate and use subjects of economic relations of administrativeterritorial entity that conduct economic activities in production and processing of their own agricultural products, which ultimately result ensures the socio-economic development of the region concerned. The role of region agricultural potential in the context of diagnostics of agricultural sector economic potential at regional level is outlined. A structural and logical diagram of the relationship between these categories is presented. The following distinctions are made between the terms: the agricultural potential of the region is characterized by the region, given the state of ownership of available resources and the prospects of attracting the necessary resources for agricultural activities, and the second category is focused on the economic feasibility of using available and the possibility of attracting resources for agricultural activities in the region. Structural-logical relationship between these categories is presented. The following distinctions between terms have been noted: the agricultural potential characterizes region, taking into account state of ownership of available resources and prospects of attracting the necessary resources for agricultural activities, and the second category is focused on the economic feasibility of using possibility of attracting resources for agricultural activities in region. It has been proposed to highlight the following potentials in assessment of agricultural potential of region: natural, industrial, economic, financial-investment, scientific-innovative, labor and quality of life in rural areas potential. The indicators are grouped into six integral indicators and compared to integrated indicators of corresponding average values in Ukraine (the growth rates for each year are calculated). The dynamics of the indicators characterizing the agricultural potential components proposed for evaluation, based on the example of Cherkasy region. Results of the survey identified trends that Cherkassy region has favorable conditions for agriculture: a significant share of capital investment, high concentration of educational and research institutions, high wages level. Due to high share of arable land, soil fertility crop sector is dominant in the region. There was established that, due to the high share of arable land, soil fertility is predominant in the field of crop production.

Keywords: potential; agricultural potential; economic potential; region 
Актуальність. В умовах динамічного соціально-економічного середовища дослідження економічного потенціалу набуває дедалі більшої актуальності, оскільки допомагає окреслити сильні та слабкі сторони, визначити можливості подальшого розвитку досліджуваного об'єкта національної економіки. Особливо це стосується економічного потенціалу пріоритетних галузей економіки, однією 3 яких як для України в цілому, так i для Черкаського регіону, зокрема, $\epsilon$ сільськогосподарська. Економічний потенціал сільськогосподарської галузі Черкаського регіону є комплексом різноманітних потенціалів, які характеризують рівень залучення та використання економічних благ у сільськогосподарській галузі на рівні регіону для забезпечення соціально-економічних потреб останнього. Однак, ефективне дослідження економічного потенціалу сільськогосподарської галузі регіону не можливе без оцінки сільськогосподарського потенціалу регіону, що перебуває в першооснові даного дослідження.

Аналіз останніх наукових досліджень та публікацій. Дослідженню соціально-економічного розвитку регіону, зокрема його економічного потенціалу, присвячено праці: М. В. Макаренка, Н. В. Сментиної. Значна частина дослідників розглядає у своїх роботах окремі складові сільськогосподарського потенціалу, зокрема: 3. Рижок, А. М. Пугач, А. В. Ключник. Однак, маловивченою залишається сфера дослідження теоретико-методологічного характеру сільськогосподарського потенціалу регіону.

Метою даного дослідження $є$ обгрунтування доцільності застосування запропонованого підходу оцінювання сільськогосподарського потенціалу регіону на прикладі Черкаського регіону у контексті діагностики економічного потенціалу сільськогосподарської галузі регіону на сучасному етапі розвитку.

Виклад основних результатів дослідження. Традиційно, під категорією «економічний потенціал регіону» розуміють «сукупність потенціалів регіону, залежно від особливостей розвитку території регіону, а також відповідних механізмів i часу їх залучення в господарський оборот 3 метою підвищення рівня конкурентоспроможності й соціально-економічного розвитку регіону» [1, с. 13], з метою «забезпечення виробництва максимально можливого обсягу матеріальних послуг, відповідних потребам суспільства на даному етапі його розвитку» [2, с. 218].

Що стосується терміну «економічний потенціал сільськогосподарської галузі регіону», він $є$ менш дослідженим серед науковців. Існуючі напрацювання спрямовано на вивчення окремих 
складових, зокрема: фінансового, ресурсного (зокрема, земельного), виробничого, експортного та інших потенціалів. У той же час, при дослідженні потенціалу сільськогосподарської галузі на регіональну рівні можна зустріти наукові праці, зорієнтовані на визначення подібних, проте не тотожних категорій, таких як: економічний потенціал сільськогосподарських підприємств, потенціал сільськогосподарського виробництва (3. Рижок) [3, с. 175], економічний потенціал сільських територій (А. В. Ключник, А. М. Пугач, А. В. Мовчанюк) [4, с. 170-171; 5, с. 9-10; 6, с. 437-438].

Враховуючи розглянуті наукові підходи щодо дослідження сутності потенціалу сільськогосподарського виробництва на рівні окремих територіальних утворень та окремо економічного потенціалу сільських територій, запропоновано визначення для характеристики економічного потенціалу сільськогосподарської галузі регіону, під яким варто розуміти сукупність економічних ресурсів та здатність їх ефективно акумулювати i використати суб'єктами економічних відносин певного адміністративно-територіального утворення, які провадять господарську діяльність 3 виробництва (вирощування) та переробки власної сільськогосподарської продукції, що у кінцевому результаті забезпечує соціально-економічний розвиток відповідного регіону.

Забезпечення соціально-економічного розвитку регіону завдяки використанню потенціалу сільськогосподарської галузі є комплексним завданням, яке включає збільшення валового регіонального продукту, зростання обсягів торгівлі та надходжень до місцевого бюджету, підвищення інвестиційної привабливості регіону, створення робочих місць у сільськогосподарській та пов'язаних 3 нею галузях народного господарства (переробна промисловість, торгівля, транспорт тощо), розвиток підприємництва, покращення (мінімізація негативного впливу) стану екології тощо. У контексті діагностики економічного потенціалу сільськогосподарської галузі на рівні регіону важливу роль відіграє врахування сільськогосподарського потенціалу регіону (рис. 1).

На думку автора, сільськогосподарський потенціал регіону, як і економічний потенціал сільськогосподарської галузі регіону, необхідно розглядати та оцінювати як сукупність різноманітних характеризуючи показників, які запропоновано згрупувати у наступні потенціали: природній, виробничо-господарський, фінансово-інвестиційний, науково-інноваційний, трудовий та потенціал якості життя у сільській місцевості. При цьому, якщо сільськогосподарський потенціал регіону характеризує регіон, зважаючи на стан володіння наявними та перспективами залучення необхідних ресурсів для ведення 
сільськогосподарської діяльності, то друга категорія зорієнтована на економічну доцільність використання наявних та можливості залучення ресурсів для ведення сільськогосподарської діяльності у регіоні. Тому, процес діагностики економічного потенціалу сільськогосподарської галузі доцільно розпочати 3 оцінювання сільськогосподарського потенціалу регіону, що дозволяє виявити існуючі тенденції розвитку сільського господарства, галузеву специфіку виробництва, сильні та слабкі сторони та порівняти з базовим періодом або іншими регіонами.

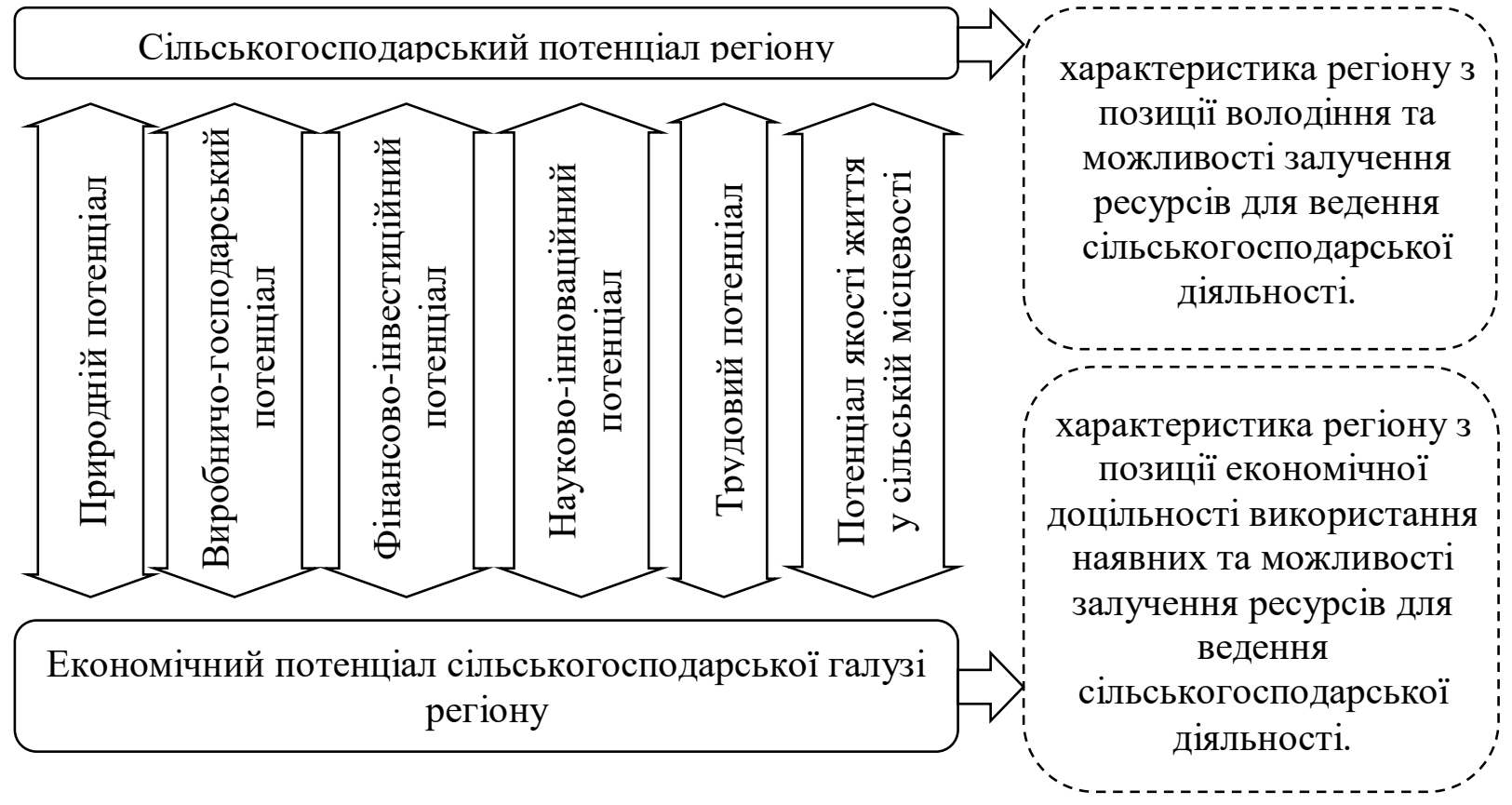

Рис. 1 Структурно-логічна схема взаємозв'язку між категоріями «сільськогосподарський потенціал» та «економічний потенціал

сільськогосподарської галузі»

Джерело: складено автором

Розглянемо більш детально показники, які характеризують запропоновані для оцінювання складові сільськогосподарського потенціалу регіону. Головним засобом виробництва галузі сільського господарства, що і вирізняє ії з поміж інших видів економічної діяльності, $\epsilon$ земля. Саме тому, дослідження природнього потенціалу зосереджене на оцінці рівня забезпечення регіону землями сільськогосподарського призначення, їх структурі та якості (ріллі для галузі рослинництва та пасовищ i сіножатих - для тваринництва). Спираючись на дані міркування, визначено наступні індикатори оцінювання природного потенціалу, зокрема: частка земель у загальнодержавному значенні, інтенсивність та раціональність використання земель, рівень пошкодження посівних площ (шкідниками, посухою), рівень використання меліорованих земель та рівень збагачення (виснаження) грунтів. 
Виробничо-господарський потенціал, який характеризує виробничий процес 3 позиції рівня забезпечення сільськогосподарської галузі регіону основними матеріальними оборотними коштами, технікою сільськогосподарського призначення та доступом до складських приміщень для збереження вирощеної продукції, запропоновано оцінювати за такими показниками, як: рівень сировинного, технічного та складського забезпечення. Не менш важливим є фінансово-інвестиційний потенціал, який розкривається через абсолютну та відносну капіталоємність галузі, доступ до кредитних ресурсів i рівень страхового покриття.

Науково-інноваційний потенціал, як перспектива та можливість інтенсивного розвитку галузі, іiі виходу на новітній щабель розвитку, характеризується такими показниками, як: чисельність науководослідницьких кадрів, фінансування наукових досліджень та розробок; охоплення вищою спеціалізованою освітою.

Рівень забезпечення регіону трудовими ресурсами (працівниками), готовими за відповідних умов вкласти у сільськогосподарське виробництво свої час, зусилля та вміння, визначає трудовий потенціал. Для оцінки даного потенціалу обрано наступні показники: землезабезпечення сільського населення, трудозабезпечення землі, рівень освіченості сільського населення, рівень старіння сільського населення. Потенціал якості життя у сільській місцевості вказує на наявність умов, які приваблюють та створюють сприятливе середовище для проживання на даній території, та складається 3 наступних показників: рівень соціальної інфраструктури, перспективи для молоді, рівень безпеки життя та праці.

Використовуючи офіційні статистичні дані, обчислено перераховані показники оцінювання сільськогосподарського потенціалу регіону на прикладі Черкаської обл., яка, зважаючи на структуру виробництва, належить до аграрно-промислового регіону (за результатами 2018 р. частка сільськогосподарської та промислової продукції у структурі ВРП області склала $27 \%$ та $26 \%$ відповідно) [7].

Для зручності оцінювання показники згруповано в шість інтегральних показників (які характеризують відповідні складові загального сільськогосподарського потенціалу) та порівняно 3 інтегральними показниками відповідних середніх значень по Україні (розраховано темпи приросту за кожен рік). Зважаючи на відмінності у веденні господарства, природний та виробничо-господарський потенціали розраховано окремо для галузей тваринництва та 
рослинництва. Інтегральний показник відповідного потенціалу $\left(Y_{j}\right)$ визначено за формулою 1 [8, с. 235].

$$
Y_{j}=\frac{1}{n}\left(\sum y_{i j}\right)
$$

де $y_{i j}$ - стандартизоване значення і-го показника - складової потенціалу;

$\mathrm{n}$ - кількість показників, за якими проводилися розрахунки.

Результати розрахунків представлено у табл. 1.

Таблиця 1 - Динаміка інтегрального показника сільськогосподарського потенціалу Черкаського регіону за 2012-2018 рр, пункти

\begin{tabular}{|c|c|c|c|c|c|c|c|c|}
\hline \multirow{2}{*}{ Назва потенціалу } & \multicolumn{7}{|c|}{ Рік } & \multirow{2}{*}{$\begin{array}{c}\text { Абсолютне } \\
\text { відхилення, } \\
2018 / 2012\end{array}$} \\
\hline & 2012 & 2013 & 2014 & 2015 & 2016 & 2017 & 2018 & \\
\hline \multicolumn{9}{|c|}{ Рослинництво } \\
\hline Природний & 0,04 & 0,04 & 0,04 & 0,03 & 0,03 & 0,03 & 0,26 & 0,22 \\
\hline $\begin{array}{l}\text { Виробничо- } \\
\text { господарський }\end{array}$ & 0,94 & 0,77 & 0,89 & 0,81 & 0,76 & 0,73 & 0,66 & $-0,28$ \\
\hline \multicolumn{9}{|c|}{ Тваринництво } \\
\hline Природний & $-\overline{35}$ & $\begin{array}{c}- \\
0,40\end{array}$ & $\begin{array}{c}- \\
0,45\end{array}$ & $\overline{-}$ & $-\overline{39}$ & -1 & $\begin{array}{c}- \\
1,04\end{array}$ & $-0,69$ \\
\hline $\begin{array}{l}\text { Виробничо- } \\
\text { господарський }\end{array}$ & $\begin{array}{c}- \\
0,18 \\
\end{array}$ & $\begin{array}{c}- \\
0,17 \\
\end{array}$ & $\begin{array}{c}- \\
0,17 \\
\end{array}$ & - & - & $\begin{array}{c}- \\
0,37 \\
\end{array}$ & - & $-0,24$ \\
\hline \multicolumn{9}{|c|}{ Сільське господарство (спільне) } \\
\hline $\begin{array}{l}\text { Фінансово- } \\
\text { інвестиційний }\end{array}$ & 1,19 & 1,22 & 1,27 & 0,93 & 0,80 & 0,57 & 1,24 & 0,05 \\
\hline Науково-інноваційний & 1,05 & 1,1 & 1,1 & 1,1 & 1,1 & 1,05 & 1,05 & 0,01 \\
\hline Трудовий & 1,24 & 1,13 & 1,08 & 1,27 & 1,3 & 1,43 & 1,43 & 0,19 \\
\hline $\begin{array}{l}\text { Потенціал якості } \\
\text { життя у сільській } \\
\text { місцевості }\end{array}$ & 1,75 & 1,78 & 1,64 & 1,96 & 1,90 & 2,1 & 2,1 & 0,35 \\
\hline
\end{tabular}

$$
\text { Джерело: побудовано автором за даними [7; 9] }
$$

Результати оцінювання вказують на те, що Черкаський регіон володіє сприятливими умовами для розвитку рослинництва. Так, 88 \% сільськогосподарських земель регіону складає рілля. До того ж, майже чверть продукції рослинництва (23,2\%) вирощується сільськими домогосподарствами області. Підтвердженням переважаючої схильності господарств населення області виробляти продукцію рослинництва порівняно з тваринництвом є обсяг сільськогосподарської продукції у розрахунку на 100 га угідь. Так, сільськими домогосподарствами зі 100 га угідь зібрано 729,6 тис. грн. продукції рослинництва, що на 53,1 тис. грн. 
більше проти результатів відповідної діяльності підприємств, в той час, котрими виготовлено 459,8 тис. грн. продукції тваринництва зі 100 га землі, що на 25 \% більше за аналогічні показники домогосподарств [7].

Це досить суттєві показники, котрі характеризують господарства населення Черкаської обл., як важливих учасників сільськогосподарського сектору економіки у галузі рослинництва. Їх вклад у загальному обсязі вирощування сільськогосподарських культур області визначається наступними частками: сільськими домогосподарствами виготовлено 96,5 \% картоплі, 83,4 \% плодових та ягідних культур, 74,4\% овочевих культур, $11,7 \%$ зернових та зернобобових культур [7].

На думку автора, дана ситуація, у першу чергу, зумовлена необхідністю залучення значного обсягу людської праці, зокрема, у вирощуванні овочевих, плодових та ягідних культур. 3 одного боку, це створює додаткові витрати на оплату найманої праці, а 3 іншого продуктивність праці у господарствах населення $\epsilon$ вищою порівняно 3 сільськогосподарськими підприємствами завдяки реалізації першими особистого інтересу у реалізації раціонального та ефективного виробничого процесу. По-друге, нестача робочих місць та надлишок робочої сили у сільських місцевостях перетворюють натуральне виробництво сільгосппродукції на особистих ділянках джерелом отримання доходів. По-трете, сільські домогосподарства мають конкурентну перевагу перед суб'єктами підприємництва за рахунок спроможності реалізовувати продукцію за відносно нижчими ринковими цінами.

На противагу, галузь тваринництва $\epsilon$ менш привабливою для господарств населення, які не мають необхідного технічного, фінансового та інформаційного забезпечення. Сільськогосподарські підприємці також виявляють низьку зацікавленість у здійсненні діяльності пов'язаної з тваринництвом через високий рівень фінансових та матеріальних затрат, у результаті чого відбувається скорочення чисельності поголів'я худоби у їх користуванні.

Висновки. Діагностика економічного потенціалу сільськогосподарської галузі регіону потребує, перш за все, дослідження та оцінювання сільськогосподарського потенціалу, як характеристики регіону з позиції володіння та можливості залучення ресурсів для ведення сільськогосподарської діяльності. Запропонований підхід оцінювання сільськогосподарського потенціалу регіону передбачає дослідження шести основних складових потенціалів: природнього, виробничо- 
господарського, фінансово-інвестиційного, науково-інноваційного, трудового та потенціалу якості життя у сільській місцевості.

За результатами дослідження було виявлено, що Черкаський регіон володіє сприятливими умовами для ведення сільського господарства: значна частка капітальних інвестицій на розвиток галузі, висока концентрація навчальних та науково-дослідних установ, вище середнього по Україні рівень заробітної плати у галузі. Зважаючи на високу частку ріллі, родючість грунтів переважаючою $\epsilon$ галузь рослинництва. Перспективою подальших досліджень $є$ виявлення перспектив розвитку галузі тваринництва у Черкаському регіоні та покращення умов ведення рослинництва.

\section{СПИСОК ВИКОРИСТАНИХ ДЖЕРЕЛ:}

1. Макаренко М. В. Економічний потенціал регіону як основа його розвитку. Вісник Приазовського державного технічного університету. Серія: Економічні науки. 2017. № 34. C. 12-18.

2. Економічна енциклопедія: у 3 т. Ред. рада: Б. Д. Гаврилишин та ін. Київ: Академія; Тернопіль: Акад. нар. хоз-ва, 2002. 864 с.

3. Рижок 3. Економічний потенціал земельних ресурсів в умовах ринкових трансформацій. Вісник Львівського національного аграрного університету. Серія : Економіка АПК. 2015. № 22 (2). С. 175-180.

4. Пугач А. М. Основні положення механізму відтворення людських ресурсів в процесі забезпечення розвитку аграрного потенціалу України. Вісник Національного університету цивільного захисту України. Серія : Державне управління. 2015. Вип. 2. С. 167-174.

5. Ключник А. В. Формування та розвиток економічного потенціалу сільських територій України: монографія. Миколаїв: Дизайн та поліграфія, 2011. 468 с.

6. Мовчанюк А.В. Особливості соціально-економічного розвитку сільських територій. Черкаської області. Економіка і суспільство. 2017. № 8. С. 436-441.

7. Офіційний сайт Державного комітету статистики України. URL: http://www.ukrstat.gov.ua/

8. Сментина Н. В. Оцінка рівня соціально-економічного розвитку регіонів за результатами реалізації стратегічних планів. Вісник Одеського національного університету імені I.I. Мечникова. Серія: економіка. 2014. Том 19. Випуск 3/1. C. 233-237.

9. Офіційний сайт Головного управління статистики у Черкаській області. URL: http://www.ck.ukrstat.gov.ua 


\section{REFERENCES:}

1. Makarenko, M. V. (2017). Ekonomichnyi potentsial rehionu yak osnova yoho rozvytku [Economic potential of region as basis for its development]. Visnyk Pryazovskoho derzhavnoho tekhnichnoho universytetu. Seriia: Ekonomichni nauky. Vol. 34. Pp. 12-18. [in Ukrainian].

2. Havrylyshyn, B. D. (2002). Ekonomichna entsyklopediia [Economic encyclopedia]. (Vols. 1-3). Kyiv : Akademiia ; Ternopil : Akad. nar. khoz-va. [in Ukrainian].

3. Ryzhok, Z. (2015). Ekonomichnyi potentsial zemelnykh resursiv v umovakh rynkovykh transformatsii [Economic potential of land resources in conditions of market transformations]. Visnyk Lvivskoho natsionalnoho ahrarnoho universytetu. Seriia : Ekonomika APK. Vol. 22(2). Pp. 175-180. [in Ukrainian].

4. Puhach, A. M. (2015). Osnovni polozhennia mekhanizmu vidtvorennia liudskykh resursiv $\mathrm{v}$ protsesi zabezpechennia rozvytku ahrarnoho potentsialu Ukrainy [Main aspects of human resources reproduction mechanism in development of Ukrainian agrarian potential]. Visnyk Natsionalnoho universytetu tsyvilnoho zakhystu Ukrainy. Seriia : Derzhavne upravlinnia. Vol. 2. Pp. 167-174. [in Ukrainian].

5. Kliuchnyk, A. V. (2011). Formuvannia ta rozvytok ekonomichnoho potentsialu silskykh terytorii Ukrainy: monohrafiia [Formation and development of economic potential of Ukrainian rural territories: monograph]. Mykolaiv: Dyzain ta polihrafiia. [in Ukrainian].

6. Movchaniuk, A. V. (2017). Osoblyvosti sotsialno-ekonomichnoho rozvytku silskykh terytorii Cherkaskoi oblasti [Features of socio-economic development of Cherkassy region rural areas]. Ekonomika i suspilstvo. Vol. 8. Pp. 436-441. [in Ukrainian].

7. Ofitsiinyi sait Derzhavnoho komitetu statystyky Ukrainy [Official site of State Statistics Committee of Ukraine]. www.ukrstat.gov.ua. Retrieved from http://www.ukrstat.gov.ua/ (accessed 20 September 2019). [in Ukrainian].

8. Smentyna, N. V. (2014). Otsinka rivnia sotsialno-ekonomichnoho rozvytku rehioniv za rezultatamy realizatsii stratehichnykh planiv [Assessment of regions' socio-economic development level on results of strategic plans implementation]. Visnyk Odeskoho natsionalnoho universytetu imeni I.I. Mechnykova. Seriia: ekonomika. Vol. 19 (3/1). Pp. 233-237. [in Ukrainian].

9. Ofitsiinyi sait Holovnoho upravlinnia statystyky u Cherkaskii oblasti [Official site of Main Department of Statistics in Cherkassy region]. www.ck.ukrstat.gov.ua. Retrieved from http://www.ck.ukrstat.gov.ua (accessed 20 September 2019). [in Ukrainian]. 